\title{
Fisheries first to suffer
}

\section{Berkeley}

A HUGE clean-up operation continued last week in Alaska's Prince William Sound, the site of the largest oil-tanker spill in US history. As the main oil slick moved southwest, out of the sound, it left behind smaller slicks, hundreds of miles of contaminated shoreline and more than 1,400 square miles of fouled waters. The wrecked tanker Exxon Valdez was floated from the reef where it had run aground and towed to a nearby island for repairs.

The captain of the tanker, Joseph Hazelwood, is said to have been under the influence of alcohol and absent from the bridge at the time of the accident. Coast Guard investigators were told by at least one crew member that Hazelwood had placed the ship on automatic pilot on an erroneous collision course with the reef.

Hazelwood, wanted in Alaska on misdemeanour charges associated with the spill, surrendered to the authorities in his home state of New York last week. A New York judge set his bail at $\$ 1$ million, after pointing out the magnitude of the disaster, but a second judge later reduced bail to $\$ 25,000$.

The oil contaminated a large portion of the herring-spawning grounds in Prince William Sound. Last week, Alaska Fish and Game officials cancelled the herringroe fishery that would normally have opened several weeks ago. Paul Ruesch, a state fisheries biologist, said both herring eggs and young larvae are highly susceptible to toxic hydrocarbons. "We couldn't justify additional mortality from the fishery", he said. There is also a risk that the roe may be contaminated and therefore unsaleable. The fishermen, who stand to lose $\$ 12$ million, hope to recover damages from Exxon.

This year's \$70-million salmon fishery, due to begin in early summer, may escape serious damage from the spill, but the catch in future years is likely to be reduced if the oil affects this year's young. Fishermen continued to set floating booms to keep oil out of the bays that house the area's four salmon hatcheries.

But Ruesch acknowledged that success with booms has been "spotty", and the hatcheries are largely at the mercy of the winds. If large amounts of oil come their way, salmon fry reared in captivity may be caught at a vulnerable stage when they are being transferred to salt-water pens ready for their May release. Wild fry which are beginning to emerge from gravel beds will also be at risk.

The level of toxins in the sound, and their effect on the plankton, is not yet known, as water sampling has just begun. Various agencies are preparing for longterm studies of the effects of the oil on water quality, sediments and beaches.
"There will undoubtedly be some very long-term persistent impacts", said Ruesch. "Prudhoe Bay crude does not weather well; it doesn't break up and it doesn't sink. It is very persistent."

The sound has the largest concentration of sea otters in the world, according to Mark Kuwada, a habitat biologist with the fish and game department. Kuwada said that 30 per cent of the sound's 5,000 sea otters live in areas affected by the spill, although it is not known how many have died.

Thousands of waterfowl have been killed by the oil, and the sound's large population of endangered bald eagles has been reported to be feeding on the contaminated carcasses, although no dead eagles have yet been found. Two deer were found dead after apparently feeding on seaweed tainted with oil.

President Bush last week made available US military troops to help clean up the spill, acknowledging that Exxon's efforts were insufficient. He emphasized that the government was not "federalizing" the clean-up operation, and that Exxon would still be responsible for costs.

Environmentalists say an accident such as this was inevitable, given Alaska's laxity in monitoring the oil industry, which supports 85 per cent of the state's economy. Mike Matz, of the Sierra Club, said Alaska's Department of Environmental Conservation, which is responsible for approving the oil industry's contingency plan for clean-up of spills and for assuring that the industry maintains the promised level of preparedness, lacks adequate funds and has been unable to carry out adequate monitoring. Even when permit violations were discovered, said Matz, political pressures prevented prosecution of the violators.

Although the spill has not changed the Bush administration's support for oil exploration in Alaska's Arctic National Wildlife Refuge (ANWR), public outrage over the accident has slowed the progress through Congress of a bill to authorize the exploration, while both houses hold hearings on the causes and potential effects of the accident. Congressional representatives from California have used the spill to fuel their protest against the opening of areas off the California to oil exploration. Interior secretary Manuel Lujan $\mathrm{Jr}$ warned oil industry representatives last week that the Valdez accident could have an effect on the oil industry similar to that of the Three Mile Island accident on nuclear power. "If the image of an uncareful and uncaring industry prevails among the public", he said, "then we can kiss goodbye to domestic oil and gas development in ANWR, offshore, and in the public lands."

\section{Worries about future Paris}

THE French research minister, Hubert Curien, has set up two working parties with unions representing researchers to find ways to protect the future of their profession. One will consider the problem of recruitment of young researchers to the major state research organizations, such as INSERM and CNRS, while the other will look at career prospects, with the accent on greater mobility of trained researchers towards universities and industry.

The unions are pessimistic about the negotiations. Robert Descimon, general secretary of SNCS, the biggest union representing full-time researchers, fears that the government is dismantling the state research organizations in favour of the universities, whose research role in many disciplines is relatively small. Most research is carried out in state organizations, where researchers have jobs for life and a small teaching load. But a slowing in the number of new posts has created a bottleneck of young postdoctoral researchers seeking their first job, with a resulting rise in the average age of researchers. Meanwhile, salaries are becoming increasingly unattractive compared with those offered by industry, even to untrained researchers.

In his pre-election "letter to the French people", President François Mitterrand declared that research would be a national priority. "There is not much evidence of this so far", says Descimon. Most of the government effort, he says, is directed towards major reforms of education, including higher education. The unions fear that trained researchers will be drained from the state research organizations in order to inject new blood into the universities, without the promised reevaluation of research as a career.

Peter Coles

\section{JAPAN \\ Electronic Leonardo}

\section{Tokyo}

JAPANESE art lovers who want to see the Mona Lisa but cannot make the trip to the Louvre may soon be able to enjoy the next best thing. A new art gallery in Gifu, central Japan, is using high-definition television (HDTV) to display works of art recorded digitally on compact discs.

HDTV, which was first developed by Japan's National Broadcasting Corporation (NHK), has twice as many lines on the screen as conventional television and produces images of exceptional clarity.

The Gifu Museum of Fine Arts is using the system to show pictures from its collection which it does not have room to put on display. In the future, museum officials hope to import HDTV images from art galleries all over the world so that visitors will be able to view famous works of art at the push of a button. David Swinbanks 